\title{
四肢の巨大悪性軟部腫瘍の予後
}

\author{
長崎大学整形外科 \\ 神代敏之・平野徹 \\ 岩 崎 勝 郎
}

\section{Prognosis of Soft Tissue Sarcomas in Extremities}

by

\author{
Toshiyuki Kumashiro, Toru Hirano and Katsuro Iwasaki \\ Department of Orthopaedic Surgery, \\ Nagasaki University School of Medicine, Nagasaki
}

\begin{abstract}
We studied the relation between tumor size and prognosis in soft tissue sarcomas of the extremities in 43 patients. Soft tissue sarcomas over $10 \mathrm{~cm}$ in diameter of 26 patients were located in the lower extremities (poximal thigh: 19 patients), and of those, 13 patients had a local recurrence. In the 17 patients whose sarcomas were less than $10 \mathrm{~cm}, 13$ patients were resected with inadequate margin, and 5 had a local recurrence.

The 5 and 10-year survival rate of the patients with the tumors over $10 \mathrm{~cm}$ was lower than those with ones less than $10 \mathrm{~cm}$. The prognosis was poor in the 18 patients with a local recurrence. This indicates that local control of soft tissue sarcomas is important for improving their prognosis.
\end{abstract}

\section{はじめに}

悪性軟部腫瘍の生命的予後に関しては，すでに組織 学的診断と細胞異型性が強いものほど, また腫瘍が大 きいものほど予後不良であることが指摘されてい

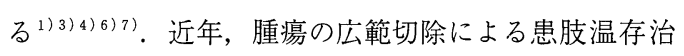
療が盛んに行われているが, 腫瘍の発生部位や大きさ と局所根治性との関係についての報告は少ない2)5). そこで今回, 我々は, 四肢に発生した巨大な悪性軟部 腫瘍（最大径が $10 \mathrm{~cm}$ 以上のもの）の予後を臨床的 に検討した。

\section{対象および方法}

当科で治療した四肢原発の悪性軟部腫瘍のうち, 1969 年から 1989 年の期間に手術を行いその後経過観 察した 43 例を対象とした。 その内訳は男性 21 例, 女 性 22 例で, 年齢分布は 3 歳から 76 歳, 平均 37.6 歳 である. 観察期間は死亡例では最短術後 7 力月から最 長 8 年 11 力月, 生存例では 2 年 1 力月から 12 年 6 力 月, 平均 5 年 3 力月である. 組織学的診断は, 悪性線
維性組織球腫 13 例, 滑膜肉腫 9 例, 脂肪肉腫 7 例, 横紋筋肉腫 5 例, 平滑筋肉腫 3 例, 悪性血管外皮腫 3 例, 線維肉腫 1 例, 分類不能例 2 例であった. 初回治 療は患肢温存手術 41 例, 切離断術 2 例で, 術前術後 の補助的治療は放射線療法のみ 10 例, 化学療法のみ 3 例, 両者併用 24 例で, 手術単独は 6 例であった. 腫瘍切除縁については日整会の骨・軟部肉腫切除縁評 価法に準じて評価した。

これらの症例を腫瘍の最大径が $10 \mathrm{~cm}$ 以上の症例 の 26 例と, $10 \mathrm{~cm}$ 未満の症例 17 例に分け，それぞれ における発生部位別や, 腫瘍切除縁別の局所再発症例 数と, 累積生存率を Kaplan Meier 法で求め, カイ 二乗検定で比較した．統計的に危険率 $5 \%$ 以下を有意 差ありとした.

結果

発生部位別の症例数を図 1 に示す，腫瘍最大径 10 $\mathrm{cm}$ 未満では大腿部 6 例, 下腿部 3 例, 上腕部 2 例, 肘部 4 例など四肢の各部位にみられた。これに対して 最大径 $10 \mathrm{~cm}$ 以上の 26 例は全例下肢に発生しており, 


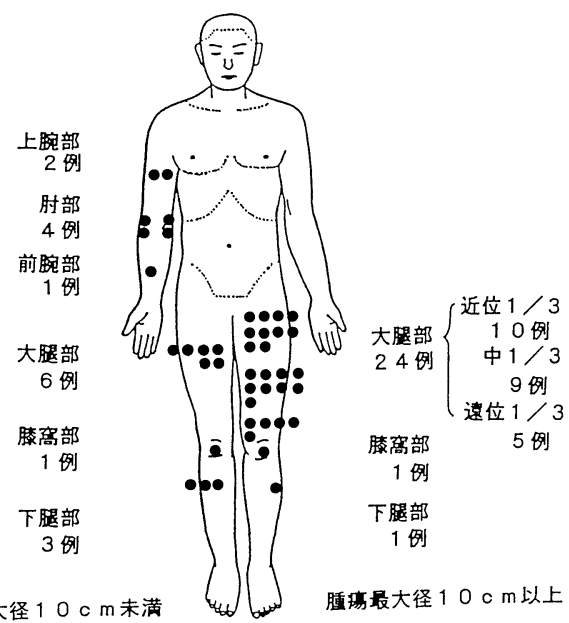

図 1 腫瘍発生部位と症例数: 腫瘍最大径 $10 \mathrm{~cm}$ 以上 では全例下肢に発生しており，なかでも大腿部 に多く発生していた。
なかでも大腿部に 24 例と圧倒的に多く発生していた。 また大腿部のなかでも，近位 $1 / 3$ が 10 例，中 $1 / 3$ が 9 例，遠位 $1 / 3$ が 5 例と躯幹近位部に多く発生し ていた.

腫瘍切除縁では wide margin であったもの 9 例, marginal margin 18 例, intralesional margin 14 例で，初回治療時切断したものが 2 例であった。 これを wide margin であったものと，それ以外の もの，㧍よび，腫瘍最大径 $10 \mathrm{~cm}$ 以上のものと $10 \mathrm{~cm}$ 未満とで比較したが，有意の関連は認めなかった。し かし，これを部位別にみてみると，腫瘍最大径 $10 \mathrm{~cm}$ 以上の症例で，大腿近位部と肘部内側に発生したもの では intralesional margin となったものが多かっ た(表 1 ).

局所再発は腫瘍最大径 $10 \mathrm{~cm}$ 以上で 13 例（50\%）, $10 \mathrm{~cm}$ 未満で 5 例（29\%）に見られ，前者が頻度は高 かったが，有意の差はなかった。部位別には最大径 $10 \mathrm{~cm}$ 以上の症例で，大腿近位部では 10 例中 8 例と

表 1 各切除縁に扔ける腫瘍の大きさ及び発生部位別の症例数

\begin{tabular}{|c|c|c|c|c|}
\hline 部位 〉 & margin & wide & marginal & intralesional \\
\hline \multicolumn{2}{|c|}{ 腫瘍最大径 $10 \mathrm{~cm}$ 以上 } & 5 & 12 & 7 \\
\hline \multirow[t]{3}{*}{ 大腿部 } & 近位 $1 / 3$ & 1 & 4 & 5 \\
\hline & 中 $1 / 3$ & 3 & 5 & 1 \\
\hline & 遠位 $1 / 3$ & 1 & 1 & 1 \\
\hline \multicolumn{2}{|l|}{ その他 } & 0 & 2 & 0 \\
\hline \multicolumn{2}{|c|}{ 腫瘍最大径 $10 \mathrm{~cm}$ 未渵 } & 4 & 6 & 7 \\
\hline \multicolumn{2}{|c|}{ 大腿部 } & 2 & 2 & 2 \\
\hline \multirow{2}{*}{ 肘部 } & 外側 & 1 & 1 & 0 \\
\hline & 内側 & 0 & 0 & 2 \\
\hline \multicolumn{2}{|c|}{ その他 } & 1 & 3 & 3 \\
\hline \multicolumn{2}{|c|}{ 計 } & 9 & 18 & 14 \\
\hline
\end{tabular}

表 2 腫瘍の大きさ別, 切除縁別の局所再発症例数

\begin{tabular}{|c|c|c|c|}
\hline & $(+)$ & $(-)$ & \\
\hline 腫瘍最大径 $10 \mathrm{~cm}$ 以上 $(\mathrm{n}=26)$ & 13 & 13 & \\
\hline 腫瘍最大径 $10 \mathrm{~cm}$ 未満 $\quad(\mathrm{n}=17)$ & 5 & 12 & . \\
\hline wide margin $(n=9)$ & 1 & 8 & $\longrightarrow$. \\
\hline marginal margin 以下 $(n=34)$ & 17 & 17 & 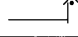 \\
\hline
\end{tabular}


高頻度に局所再発がみられた. また, $10 \mathrm{~cm}$ 未澫の症 例でも肘部では 4 例中 3 例に局所再発がみられた. wide margin が得られていながら再発が認められた のは腫瘍最大径 $10 \mathrm{~cm}$ 以上の 1 例のみで, 局所再発 と腫瘍切除縁との間には有意の関連が認められた（表 2 ).

Kaplan-Meier 法による全症例の 5 年累積生存率 は $62 \%$ あった（図 2 ）. 組織型別の累積生存率では, 悪性線維性組織球腫, 滑膜肉腫, 脂肪肉腫, 横紋筋肉 腫の 5 年累積生存率は，それぞれ $66 \% ， 56 \% ， 71 \%$, 40\%であり，それぞれに有意差は認めなかった。また， 腫瘍最大径 $10 \mathrm{~cm}$ 以上と $10 \mathrm{~cm}$ 未満に分けた累積生 存曲線を示す. 最大径 $10 \mathrm{~cm}$ 以上の 5 年累積生存率 は $53 \%$ であったのに対し, $10 \mathrm{~cm}$ 未満では 5 年累積 生存率が $74 \%$ とこの 2 群間には有意差が認められ た. また，局所再発が認められた症例の 5 年累積生存 率は $50 \%$ であった。

\section{考察}

間葉系組織から発生する悪性軟部腫瘍の組織型は豊 富であり，同一組織型であってもその予後には，多く の因子が関与している7). Berlin et al. ${ }^{1)}$ は年齢と 生検の有無が局所的予後に, 年齢や組織学的悪性度お よび切除縁が生命的予後に関与していると報告してい る. Ruka et al. ${ }^{4)}$ は年齢, 性 (女性), 大きさ, stage (American Joint Committee), 切除縁が, Torosian et al. ${ }^{6)}$ は組織学的悪性度, 大きさ, 発生部位 が生命的予後に関与していると述べている。このよう に報告者により異なるが, 切除縁が局所的および生命 的予後因子の一つであることは間違いない5). Collin et al. ${ }^{2)}$ は, 腫瘍の最大径が $10 \mathrm{~cm}$ をこえ躯幹の近位 部に存在するものは生存率が悪いと報告しているが, 本研究でも同様な傾向がみられた。

患肢温存治療では, 機能をより良くするため必要最 低限の切除が望まれる．腫瘍が大きいとこれが，つい つい不十分な切除になることが予想されるがこの点に 注目した報告は少ない. 本研究の結果から, $10 \mathrm{~cm}$ 以 上の悪性軟部腫瘍の予後は $10 \mathrm{~cm}$ 未満のものに比べ 悪かった.これには局所再発の有無が左右しているも のと考えられ，このことに関与していると思われる大 腿部近位 $1 / 3$ には, 解剖学的に重要な神経・血管が 走行しているため, 手術時の操作が繁雑な場合がある

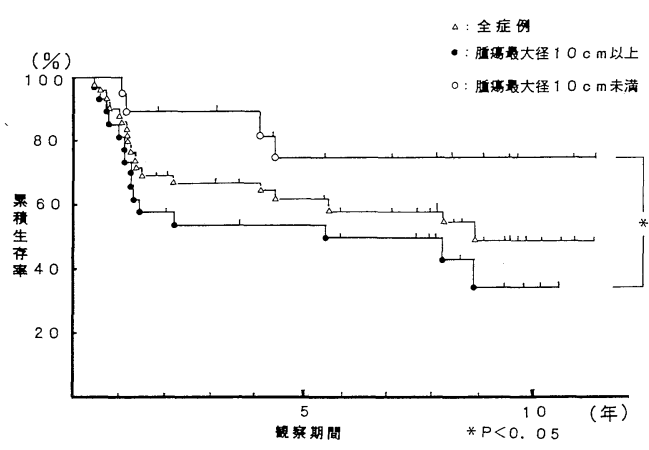

図 2 全症例および腫瘍大きさ別累積生存曲線： Kaplan-Meier 法による累積生存曲線を示す。 全症例の 5 年累積生存率; $62 \%$, 腫瘍最大径 10 $\mathrm{cm}$ 以上と腫瘍最大径 $10 \mathrm{~cm}$ 末満の症例の 5 年 累積生存率はそれぞれ $53 \% ， 74 \%$ で，5\%の 危険率で有意差が認められた.

うえ, 深部に発生しやすい.また術後の患肢機能を考 えるあまり切除縁が甘くなる可能性があり, 患肢温存 手術時には特に注意をはらう必要があると思われた。

\section{ま と め}

(1)当教室で治療した四肢原発悪性軟部腫瘍 43 例を， 腫瘍最大径 $10 \mathrm{~cm}$ 以上（26例）と $10 \mathrm{~cm}$ 未満（17例） に分け，発生部位，腫瘍切除縁，局所再発，生命的予 後について比較した

(2)腫瘍最大径 $10 \mathrm{~cm}$ 以上の症例の発生部位は, 大 腿近位部が多く, 同部での腫瘍切除縁は intralesional margin が，また局所再発も多かった．腫瘍切除縁と 局所再発との間には有意の関連が認められた。

(3)腫瘍最大径 $10 \mathrm{~cm}$ 以上の 5 年および 10 年累積生 存率は, $10 \mathrm{~cm}$ 末満のものに比べ有意に低下していた。

(4)腫瘍最大径 $10 \mathrm{~cm}$ 以上の悪性軟部腫瘍の予後は $10 \mathrm{~cm}$ 未満のものに比べ覀く，切除確保を厳重に考え る必要性が示唆された。

\section{文献}

1) Berlin, O. et al.: Surgery for soft tissue sarcoma in the extremities. Acta Orthop. Scand. 61 (6) : 475486, 1990.

2) Collin, C. F. et al.: Prognostic factors for lacal recurrence and survival in patients with lacalized extremity soft-tissue sarcoma. Semin. Surg. Oncol. 
4:30-37, 1988.

3) Lack, E. E. et al.: Extremity soft tissue sarcomas: Analysis of prognostic variables in 300 cases and evaluation of tumor necrosis as a factor in stratifying higher-grade sarcomas. J. Surg. Oncol. 41 : 263273, 1989

4) Ruka, W. et al.: Clinical factors and treatment parameters affecting prognosis in adult high-grade soft tissue sarcomas: a retrospective review of 267 cases. Eur. J. Surg. Oncol. 15 : 411-423, 1989.

5) Simon, M. A. and Enneking, W. F.: The management of soft-tissue sarcomas of the extremities. J. Bone and Joint Surg. 58-A : 317-327, 1976.

6) Torosian, M. H. et al.: Soft-tissue sarcoma: Initial characteristics and prognostic factors in patients with and without metastatic disease. Semin. Surg. Oncol. 4 : 13-19, 1988.

7）上田孝文他：軟部肉腫の㧍ける組織学的予後因子の検
討. 別冊整形外科, $17: 44-50,1990$.

質 問州大学 中馬 広一 Intralesional resection というと 2 つの状況が考 えられると思います。 satellite lesion 等があり， intra lesional となったのか，それとも腫瘍近傍に 切り込みすぎたという症例との割合はどの程度でしょ うか.

\section{解 答神代 敏之}

術後の標本で intralesional margin と分類した. これは，術中に腫瘍組織にはいったと思われた症例， 又は昔の症例で，切除縁が甘かったものが含まれてい る. 